\title{
A SOCIO ECONOMIC STUDY ON WOMEN MICRO ENTREPRENEURS - WITH SPECIAL REFERENCE TO STREET VENDORS IN KARAIKUDI CITY, TAMIL NADU, INDIA
}

\author{
T. Murugesan \\ Centre for Women's Studies, Alagappa University, Karaikudi, Tamil Nadu, India
}

\begin{abstract}
The women street vendors have occupied the streets, their activities and motivations have remained poorly understood. As the economic melt-down worsens as epitomize by company closures on a mass scale, more and more people find themselves depending on street vending for their livelihoods. Informal businesses in general and street vendors in particular are commonly considered to be typical informal workers who invariably escape compliance with state regulations of their business enterprises. But, what is the nature of street vending in Karaikudi? What are the modalities and operations of street vendors in Karaikudi? What challenges have been brought by street vending? These were the overarching issues addressed in this study.
\end{abstract}

Keywords: Women, Micro Credit, Street vendors, Empowerment

\section{INTRODUCTION}

Marginality is an experience that affects millions of people throughout the world. People who are marginalized have relatively little control over their lives, and the resources available to them. This results in making them handicapped in delving contribution to society. A vicious circle is set up whereby their lack of positive and supportive relationships means that they are prevented from participating in local life, which in turn leads to further isolation. This has a tremendous impact on development of human beings, as well as on society at large. As the objective of development is to create an enabling environment for people to enjoy a productive, healthy, and creative life, it is important to address the issue of marginalization. Development is always broadly conceived in terms of mass participation. Marginalization deprives a large majority of people across the globe from participating in the development. It is a complex problem, and there are many factors that cause marginalization. This complex and serious problem need to be addressed at the policy level. This project deals with the problems associated with the groups suffering from marginalization and the ways to reduce them.

Women - Under different economic conditions, and under the influence of specific historical, cultural, legal and religious factors, marginalization is one of the manifestations of gender inequality. In other words, women may be excluded from certain jobs and occupations, incorporated into certain others, and marginalized in others. In general they are always marginalized relative to men, in every country and culture. Women (or, men) don't present a homogeneous category where members have common interests, abilities, or practices. Women belonging to lower classes, lower castes, illiterate, and the poorest region have different levels of marginalization than their better off counterparts.

\section{Street Vendors}

Street vendors are the most visible section of the informal economy. Street vending as a profession has been in existence in India since times immemorial. In cities of Tamil Nadu, the large numbers of urban poor survive by working in the informal sector. Poverty and lack of gainful employment in the rural areas of Tamil Nadu and in the smaller towns drive large

Corresponding Author: tmurugeshmuthu@gmail.com 
numbers of people to the capital city for work and livelihood. These people generally possess low skills and lack the level of education required for the better paid jobs in the organized sector. Besides, permanent protected jobs in the organized sector are very low in Tamil Nadu; hence even those having the requisite skills are unable to find proper employment. For these people, hawking/street vending is one of the means of earning a livelihood, as it requires minor financial input and the skills involved are low and also no entry level barriers in this job.

Street vendors have been defined in the National Policy of Urban Street vendors, 2004 by Govt. of India "A street vendor is broadly defined as a person who offers goods for sale to the public without having a permanent built up structure but with a temporary static structure or mobile stall (or head load). Street vendors may be stationary by occupying space on the pavements or other public/private areas, or may be mobile in the sense that they move from place to place carrying their wares on push carts or in cycles or baskets on their heads, or may sell their wares in moving trains, bus etc. In this policy document, the term urban vendor is inclusive of both traders and service providers, stationary as well as mobile vendors.

Women are almost half the adult population. They contribute two third of the world's working hours and yet earn only $1 \%$ of the world's property. In developing countries the reality of most women is that they are compelled by poverty to seek and income, either as the sole earner of the family or to supplement income of the family. Globalization is causing shrinking of the organized sector accompanied by the expansion of informal sector. Economic opportunities created by the liberalization are highly unequal. Those who are skilled, have access to market, have better links, have been able to benefit, for women of upper class, the quality as well as opportunities for employment have improved. But for most women workers however, the quality of employment is poor without any skill or access. The rise of female participation in the informal sector is more due to economic compulsion than any change in work ethos. In a labor surplus economy like India's with low employment avenues and increasing cost of living females have been increasingly pushed into labor market. In the informal sector in urban areas where women are not generally engaged in agriculture, they are engaged as weavers, vendors, constructional laborers, domestic servants etc. As defined by ILO in 1991, the term ,informal sector refers to very small scale units producing and distributing goods and services consisting largely of independent self-employed producers in urban areas of developing countries some whom also employ family labour or a few hired workers or apprentices, which operate with very little capital or none at all, which utilizes low level of technique and skill, which therefore operate at a low level of productivity which generally provide very low irregular income and highly unstable employment to those who work in it. It is informal in the sense that they are for the most part unregulated and unrecorded in official statistics. They tend to have little or no access to labour markets, to credit institution, to formal education and training institution or to many public services and amenities.

They are not recognized, supported and regulated by the government, they are often compelled by circumstances to operate outside the law and even when they are registered and respect aspects of laws they are almost invariably beyond the pale of second protection, labour legislation and protective measures at work place. Informal sector producers and workers are generally unorganized and in most cases beyond the scope of action of trade union and employers organization and they generally live in appalling, often dangerous and unhealthy condition even without basic sanitary facilities in the shanty towns of urban areas The workers of the informal sector work as piece workers, self-employed workers, paid workers in the informal enterprises, unpaid workers in family business, casual workers without fixed employer and sub-contract workers linked to the formal enterprises. Vendors are self employed workers. According to Mukhopadhyay, ,the boundary of the informal sector is obtained by the standard exclusion principle, i.e., what does the sphere of formal sector not covered is informal sector. The sector includes petty self-employed small units, of factory production employing 7-10 persons, shops and other establishments. Thus entire sector is a heterogeneous mix in which workers are not protected by labor legislation rules. People migrate from rural subsistence sector to the urban commercial sectors. The holding sector is in actual practice the 
urban traditional or unorganized sector, which absorbs the rural migrants initially in what are called the informal economic activities such as hawking, pedaling, retailing of consumer goods, working in household repair shops, carrying head loads, pushing carts, plying manual rickshaw and so on. However, by its very nature this sector offers insecure jobs and low wages or returns" ${ }^{\text {" }}$ According to Harold Lubell the informal sector constitute the residual labor market of the last resort, characterized by selfemployment and low income producers of marginal goods for lack of any other means of earning a livelihood. It is also identified as a reservoir of traditional and modern skills, which can be made productive, if effective demand is created for them. Based on the nature of their activity, vendors, so called petty traders can be categorized as ,street vendors", „small petty vendors" and ,petty vendors". Petty vendors have fixed space with proper shelter for conducting their trade which in turn allows them to invest more. Small petty vendors conduct the trade at a fixed space but without proper shelter. Street vendors carry their activity moving around the streets either carrying head loads or by using a push cart. In the towns of sivagangai district only small petty vendors are seen.

Working Pattern of the women Street Vendors: Karaikudi town is one of the famous in Tamil Nadu. Most of the Street Vendors are selling the goods like Fruits and Vegetables, Foods, Nuts, Steel, Plastic, Flowers and etc. They have a pattern of selling the goods so to say, in sitting position, bicycle, trolley, walking, sales setting of open places, road side, and door to door. They sell their goods; take the time of 12 or 14 hours per day (8AM-9PM). In this working time vendors are facing many problems from the public and some police personnel. Their working area is not protected from the harmful weather conditions like heat, rain, dust and lack of storage facilities. So their physical condition severely and causes many disease like body heat, some pimples in body, skin allergic, dust allergic and various psychological problems. Problem Faced by Street Vendors: The Street Vendors are the most internal working section of the human society. But they are facing lot of problems. Following are the troubles. Harassment by Police and Local government: Some of the police man is daily collecting the money from the Street Vendors (Rs.10-20). They buy goods from them as free of cost, and then monthly booked in 2 illegal patty cases. Police man utters bad words to them. Trading sites too small: The Street Vendors are occupied the small place and they are using some different equipments (transitory). And government announces the tender notifications but they are not interested in participating in the tenders. Problems with site allocation systems: They have no particular site for vending area. So some vendors occupy their area in early morning and it leads to quarrel between the vendors. Sometimes these problems have been taken to the court.

Lack of facilities (e.g. shelters, storage): Hawkers are not having a permanent place. They move one place to another place, so they are not using cold storage and some safety equipments (umbrella, water and etc...).

Lack of access to credit: The vendors are not able to invest lot of money (capital) for their business, because they have no enough income. This is the very difficult for their future savings.

Lack of (business) skills and education: Every human being is capable in doing work with their skill. Some vendors are entering newly in this work, because they have shy and people are not interested in buying their goods. Some vendors are not educated (below 5th standard), so they loss their money in (some people cheating their goods) business.

\section{Occupational Health and Safety for Street Vendors}

Working outside, street vendors and their goods are exposed to strong sun, heavy rains and extreme heat or cold. Unless they work in markets, most don't have shelter or running water and toilets near their workplace. Inadequate access to clean water is a major concern of prepared food vendors. Street vendors face other routine occupational hazards. Many lift and haul heavy loads of goods to and from their point of sale. Market vendors are exposed to physical risk due to a lack of proper fire safety equipment, and street vendors are exposed to injury from the improper regulation of traffic in commercial areas. 


\section{Micro Entrepreneurs}

- Micro enterprise is an effective instrument of social and economic development.

- The micro finance is agenda for empowering poor women.

- Rural women's participation in agrobased activities

This is mainly due to the fact that most of the work done by the women at farm and home is unseen as daily tasks. Automation and easy availability of labour provide more time to energetic women to engage themselves in self-employment or entrepreneur ventures.

- Micro enterprise and small business has always played a significant role in the economic development of a Country.

- Its role might not have been as amazing as that of the large corporation involving the employment of vast physical, financial and human resources.

- However, the collective impact of the multitude of micro enterprises has been great, particularly in the area of job creation.

- Women entrepreneurs' play an important role in local economies and a large percentage of micro-enterprises in developing countries are undertaken by women.

- In developing country like India where economic status of women is very weak especially in rural areas and opportunities of earning are very less in this scenario the Self Help Groups (SHGs) have covered the way for economic independence of rural women.

\section{Women have provided to be good entrepreneurs} for the following reasons:-

- Economic independence.

- Establishing own credit idea.

- Social Identity.

- Achievement of excellence.

- Confidence.

- Status in society.
- Greater freedom and mobility.

\section{Challenges faced by Women Street Vendors}

- Street Vendors faces many problems as they are vulnerable population, who are neither protected by government, NGOs, labour union nor by any labour law. They are deprived by laws made by government in respect of labour union.

- The street vendors always suffer competition with other street vendors because of fluctuation in market prices, insecure and irregular employment. Their incomes are often minimal and their sales fluctuate. Another reason for decrease in income of street vendors is that they are forced to pay 15 to 20 percent of their daily income as bribes to local police.

- Street vendors are usually associated with encroachment of public spaces, causes traffic congestion, inadequate hygiene, and poor waste disposal. Safety of food has been increasingly become a concern in regard to street vendors. No Government agency is authorized to verify the content of food as they are not regulated by any government agency.

- The government does not recognize the contribution of street hawkers towards economic and social well-being of urban population. They survive without government support. But lately, government has passed "Street Vendors Bill 2013 $3^{\text {eeee }}$, which protects the rights of street vendors.

- Negative impact of online shopping on retailers and street vendors- Online shopping is a form of electronic commerce whereby consumers directly buy goods or services from a seller over the internet without an intermediary service. Online shopping has become the trend and the new mode of purchasing. There are around 1000s of online marketing enterprises selling cosmetics, clothes, shoes, accessories, vitamin supplements, etc. literally the entire range of consumer items. The trend is very clear; retail shop demand will fall and 
even shrunk. Online shopping is indeed having an adverse impact on the retail sector.

- Uncertainty and insecurity: The basic problems of women street vendors is insecurity and uncertainty as their profession is considered illegal, but according to government of India assessment done in 2004 shows around $2.5 \%$ of local poor urban population survive by working in this occupation. If government provide license to street vendors, they can be protected by harassment and eviction by local authorities and local police.

- Another important aspect of challenges of women street vendor is being a women they become the victim of the crimes like eve teasing, sexual harassment, rape, human trafficking.

\section{Vital Contributors to Urban Economies}

Street vendors are an integral part of urban economies around the world, offering easy access to a wide range of goods and services in public spaces. They sell everything from fresh vegetables to prepared foods, from building materials to garments and crafts, from consumer electronics to auto repairs to haircuts.

\section{Contributions}

- The Informal Economy Monitoring Study (IEMS) revealed ways in which street vendors in five cities strengthen their communities:

- Most street vendors provide the main source of income for their households, bringing food to their families and paying school fees for their children.

- These informal workers have strong linkages to the formal economy. Over half the IEMS sample said they source the goods they sell from formal enterprises. Many customers work in formal jobs.

- Many vendors try to keep the streets clean and safe for their customers and provide them with friendly personal service.

- Street vendors create jobs, not only for themselves but for porters, security guards, transport operators, storage

providers, and others.

- Many generate revenue for cities through payments for licenses and permits, fees and fines, and certain kinds of taxes. This was true of two thirds of street vendors in the IEMS sample.

Street trade also adds vibrancy to urban life and in many places is considered a cornerstone of historical and cultural heritage. Yet street vendors face many challenges, are often overlooked as economic agents and unlike other businesses, are hindered rather than helped by municipal policies and practices.

\section{Women as Street Vendors: Where, Why, and How?}

Poor women in particular have always had to work; in many cities around the world, they work as street vendors and formal traders. They are rarely included in a country's labor statistics because they are far more likely to be working in the informal rather than the formal sector (and thus are not "counted" among the employed or economically active). Faced with a paucity of statistics on street vendors in general, and women hawkers in particular, it is difficult to quantify with any precision the extent of female participation. Street vending is one of the few readily accessible avenues of employment open to women who need to earn a living. The low cost of entry into many types of hawking and vending as well as schedule flexibility is an attractive factor for some women.

\section{Role of Women Street Vendors in India}

Women street vendors play very important role in India by generating employment and income opportunities. They sell different kinds of goods like clothes and hosiery, leather, molded plastic goods and different kinds of goods necessary for household, which are manufactured in small scale or home based industries .Street vendors provide the market for home based manufactured products as well as agricultural product . Eleven major arguments in support of street vending:

- Street vending contributes directly to overall level of economic activity and to the provisions of goods and services. 
- Citizens have constitutional right to choose their occupation and to engage in entrepreneurial activities.

- . Street vending is an actual or potential source of government tax revenues.

- Street vending serves as a social safetynet.

- Street vending is a laboratory for entrepreneurship, family business and social interactions.

- Street vending provides entrepreneurial opportunities to people who cannot afford to buy or rent fixed premises.

- Street vending greatly expand the range of places and times where goods and services can be provided, and sometimes they also offers goods and services which are not available in off-street locations.

- . Street vending brings life to dull street.

- Because of its low capital requirements and its potential mobility, street vending is a very effective way to cater for seasonal, sporadic and special demands.

- $\quad$ Street vending offers its workers considerable flexibility in working hours and levels of activity.

\section{REVIEW OF LITERATURE}

Brata Aloysius Gunadi : Conducted a study focusing on the vulnerability of Street Vendors in Java since the time when Java was hit severely by the economic crisis in 1997/1998, which also had reversed the trend of economic formalization in Indonesia. This aspire, a survey was conducted Yogyakarta and Sleman districts in Yogyakarta Special district and 122 Street Vendors in several streets in both areas. These samples consist of three groups of Street Vendors: food seller, non-food seller, and services providers. Based on this survey, vulnerability guide of Street Vendors is measured. The study found that most of Street Vendors in Yogyakarta experience vulnerability at the medium level. In general, vulnerability of food seller vendors is higher than other vendors. Vulnerability also varies across the locations of vending. Debdulal Saha : Studied the street vendors in terms of their decent work and emphasized that the role of organization /union in providing them the decent work culture. The researcher has taken 200 sample respondents for this study. This study aims at presenting that the street vendors mainly depend on money lenders for their economic and social security purposes. The hawkers take money from the money lenders at the interest of 5- 10 percent and it is mainly used for their social security purposes than the economic activities. They final fell into the trap of debt. This study reveals that they work for 14-18 hours a day. There is no safety for the street vendors in their work place. They have to face severe harassment form the local authority like police and Municipal Corporation. The study also discloses the fact that many trade unions and organization are there to help the hawkers but the number of these organizations is very few in number.

\section{RESEARCH METHODOLOGY}

\section{Statement of the Problem}

The women street vendors have occupied the streets, their activities and motivations have remained poorly understood. As the economic melt-down worsens as epitomize by company closures on a mass scale, more and more people find themselves depending on street vending for their livelihoods. Informal businesses in general and street vendors in particular are commonly considered to be typical informal workers who invariably escape compliance with state regulations of their business enterprises. But, what is the nature of street vending in Karaikudi ? What are the modalities and operations of street vendors in Karaikudi? What challenges have been brought by street vending? These were the overarching issues addressed in this study.

\section{OBJECTIVE OF THE STUDY}

- To understand the Socio-Economic conditions of women street vendors.

- To study the moralities and operation of Street Vendors

- To analysis the problems of women street vendors

- To initiate a State Level Law or Policy for street vendors so that they can be accommodated and their positive 
contributions to urban development are recognized.

Sampling Procedure: This study is mainly based on a primary survey, and therefore, the sociodemographic and economic profiles of 50 individual women street vendors are discussed. Their financial ease of understanding is also survey. The gratitude of the street vendors is then analysed, and their working conditions in terms of safety and security at the workplace are discussed. Social network has an important role to play in street vending, which has been explained thereafter. The researcher adopted purposive sampling method used.

Area of Study: Karaikudi

Tools for Data Collection: Interview Schedule

\section{MAJOR FINDINGS}

- In the study area majority of the respondents belonged to age group 40 50

- The education level is relatively very low among the women street vendors when it is compared with the literacy rate of Tamil Nadu

- All the street vendors are facing harassments in the study area.

- In the study area varied activities of street vending are taking place. Vegetable selling is done by major street vendors followed by fruit selling. Researcher finds more than 50 per cent of street vendors sell fruits and vegetables.

- In the study area almost 90 per cent of the streets vendors belong to the backward and the most backward communities.

- In the study area almost 89 per cent of the street vendors are married.

- Majority (71.3 per cent) of the street vendors feel the prices of the essential supplies are very high and upsetting. This is the major reason that leads to less use and less economic welfare.

- Majority (55.7 per cent) street vendors feel happy with the performance of Karaikudi
Corporation, the State Government of Tamil Nadu and the Union Government

- Analyzing the relationship of the street vendors with other religious communities, 71.3 per cent of the street vendors feel it is cordial.

- In the study area only 46.7 percent of the street vendors get Rs.4000/ - Rs. 6000 as their monthly income. The average annual income of India is Rs.5,0000.

- With regard to the monthly expenditure of the street vendors it is observed that they spend low on various requirements. Since expenditure is a crucial factor of economic welfare the lower expenditure leads to low consumption, lower welfare and low standard of living.

- In the study area almost all the street vendors borrow from others according to their capabilities. They lead their life only with borrowing. This shows their inability to come out of the clutches of money lenders and bankers.

- The awareness level is very high on the government schemes on smart card and free medical insurance cover among the street vendors in the study area.

- Referring equal status for women almost 64.3 per cent of the street vendors stand neutral. This shows a major portion of the street vendors are slowly on improving the status of women.

- With regard to the opinion of the street vendors, they prefer the stars of Kamal, Rajihi, Shivaji and MGR in mostly. Since 1960, Tamil Nadu politics is fully influenced by the film heroes. The politics in Tamil Nadu and the film industry are indivisible.

- Many of the street vendors like the family subject stories to view as an entertainment. This shows the strong sentiment on the family system prevailing in the study area.

- Majority of the (78 per cent) street vendors are not getting any assistance from NonGovernmental Organizations (NGOs). 
This show the street vendors are not in the focus of the NGOs.

- Majority of the respondents joining SHGs.

- Majority (71.3 per cent) of the street vendors feel the prices of the essential supplies are very high and upsetting. This is the major reason that leads to less use and less economic welfare.

\section{CONCLUSION}

It is observed that women in micro enterprises are assuming such vocation primarily out of economic necessity which has been discovered in the negative dependency ratio of these women and families. These women are not severely entrepreneurs as they do not take much risk by neither bringing vast capital wait for returns for a long period. Encouraging the women and their families to help these women to expand their scale of operations by upgrading the skills, diverting and addressing to newly emerging marketing needs, adopting innovative strategies to improve their scale of operation is necessary to make themselves survive in the competitive market. Women entrepreneurs can play a role of means in social and economic development of country like India. They faced many obstacles specifically in finance and marketing of their produce. Micro finance is playing a vital role in the success of Women Street vendors; particularly the entry of rural women in micro enterprises will be encouraged and motivated. Women can do wonder by their effective and skilled involvement in entrepreneurial activities. The women are having basic indigenous knowledge, skill, likely and resources to establish and manage enterprise

\section{SUGGESTIONS}

- To improve the education, health and employment conditions of the street women vendors in Karaikudi.

- The government can create a separate ministry or a special cell under the Ministry of Labour to look after the welfare of the workers in the unorganized sector under which the street vending falls.
- The government can assist them financially for their business activities at free rate of interest. And government can extend the subsidy to the street vendors, especially for vending perishable items.

\section{REFERENCES}

Brown A. (2006). Contested Space: Street trading, Public space, and Livelihoods in Developing Cities. Warwickshire, UK: Intermediate Technology Publications Ltd.

Dewar, D. and V. Watson. (1990). Urban Markets: Developing Informal Retailing. London: Routledge.

Nitika Diwakar \& Renu Anand, Student, MSW, MNNIT Allahabad, Socio - Economic Study on Women Street Vendors, NEW MAN INTERNATIONAL JOURNAL OF MULTIDISCIPLINARY STUDIES (ISSN: 2348-1390)

Blackmar, Elizabeth. (2006). “"Appropriating” the commons: the tragedy of property right discourse", in Setha Low and Neil Smith (eds), The Politics of Public Space. New York: Routledge, pp. 49-80. Bhowmik,

S. K. (2007). "Street Vendors in Urban India: The Struggle for Recognition", in A. Morales and J. Cross (eds), Street Entrepreneurs: People, Place and Politics. New York: Routledge, pp. 92-107.

Chen, Marty, Renana Jhabvala and Renana Nanavaty. (2004). "The Investment Climate for Female Informal Businesses: A Case Study from Urban and Rural India", Background Paper for the "World Development Report, 2005-A better Invest Climate for everyone'. Washington DC: The World Bank.

Women in informal employment: Globalizing and Organizing Street Vendor in India: An Overview Rachna, CASIRJ,5(3) ISSN 23999202 